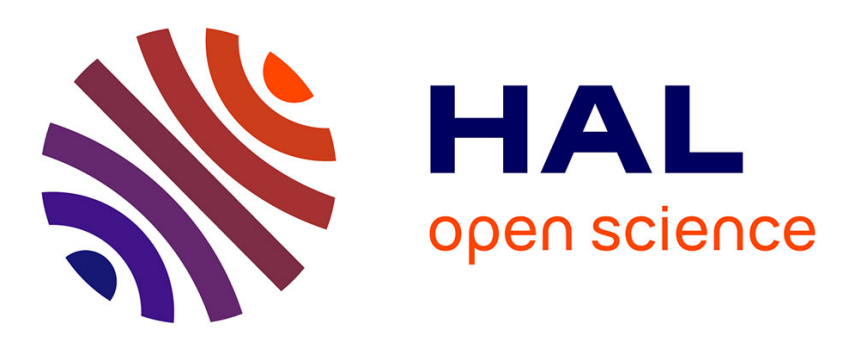

\title{
Trout sertoli cells and germ cells in primary culture: I. Morphological and ultrastructural study
}

Maurice Loir

\section{To cite this version:}

Maurice Loir. Trout sertoli cells and germ cells in primary culture: I. Morphological and ultrastructural study. Gamete research, 1989, 24 (2), pp.151-169. 10.1002/mrd.1120240204 . hal-02728173

\section{HAL Id: hal-02728173 \\ https://hal.inrae.fr/hal-02728173}

Submitted on 2 Jun 2020

HAL is a multi-disciplinary open access archive for the deposit and dissemination of scientific research documents, whether they are published or not. The documents may come from teaching and research institutions in France or abroad, or from public or private research centers.
L'archive ouverte pluridisciplinaire HAL, est destinée au dépôt et à la diffusion de documents scientifiques de niveau recherche, publiés ou non, émanant des établissements d'enseignement et de recherche français ou étrangers, des laboratoires publics ou privés. 


\title{
Trout Sertoli Cells and Germ Cells in Primary Culture: I. Morphological and Ultrastructural Study
}

\author{
Maurice Loir \\ Physiologie des Poissons, INRA, Campus de Beaulieu, Rennes, France
}

\begin{abstract}
In order to characterize trout Sertoli cells and germ cells obtained after testis dissociation and cell separation, we have studied their morphology, ultrastructure, survival, and ability to express differentiated activities in primary cultures. After dissociation, the fine structure of Sertoli cells does not differ from that observed in situ and only minor changes are shown for at least 13 days. Until they are flattened in a monolayer, they keep the ability to retain germ cells on their surface. When flattened, some of them are able to divide. At the opposite of meiotic germ cells, spermatogonia can develop independently of Sertoli cells. They are able to proliferate during at least 10 days. Spermatocytes and spermatids are obtained as single cells and multinucleated giant cells (symplasts). In the absence of somatic cells, their maximal viability is approximately 5 days, whereas spermatocytes adhering to Sertoli cells can survive at least 10-12 days, provided trout lipoproteins are present. Spermatocytes are able to differentiate to spermatids, although this process is impaired for some cells. The adhesion of spermatogonia and spermatocytes to Sertoli cells is specific, mediated by desmosome-like junctions and favored by lipoproteins. These data are compared to what is known in mammals and in amphibians.
\end{abstract}

Key words: teleost, testis, cell culture, ultrastructure

\section{INTRODUCTION}

Salmonids are seasonally breeding teleosts. Every year, a new spermatogenetic cycle is initiated by spermatogonial proliferation. Several waves of spermatogenesis lead to the accumulation of spermatozoa in the lobular lumen. After spermatogenesis has stopped and spermiation has occurred, the testes remain in a regressed state (only A spermatogonia are present) before the next cycle starts. At the present time, numerous questions dealing with endocrine and paracrine control of the various steps of a cycle remain unanswered. There are very little data available about the reciprocal interactions that exist throughout spermatogenesis between Sertoli cells and germ cells. For several years now, a large amount of literature has been available documenting various aspects of these interactions in mammalian testis [Palombi et al., 1979; Tres and Kierszenbaum,

Received January 25, 1989; accepted April 21, 1989.

Address reprint requests to M. Loir, Physiologie des Poissons, INRA, Campus de Beaulieu, 35042 Rennes Cedex, France.

(c) 1989 Alan R. Liss, Inc. 
1983; Tung and Fritz, 1984; Hadley et al., 1985; Sprando and Russell, 1987; Enders and Millette, 1988; Le Magueresse and Jégou, 1988]. A similar study in Xenopus [Risley, 1983] revealed striking differences in the metabolic germ cells/Sertoli cells interactions between mammals and amphibians. In salmonids, the topographical relationships between Sertoli cells and germ cells differ conspicuously from those known in mammals (germ cells are organized in cysts [Billard, 1986]). Thus, it was decided to try to elucidate the mechanisms involved in the spermatogenetic cycle in fish of aquacultural interest while beginning to develop a comparative study of cellular interactions in the vertebrate testis.

Because the usefulness of in vitro methodologies using populations of isolated testicular cells has been highlighted in mammals, a technique has been developed to prepare somatic cells and germ cells present in trout testes at any stage in the maturation process [Loir, 1988]. In a second step, we have characterized the various cell types obtained and checked their ability to survive and to express differentiated activities in vitro. This paper is devoted to a descriptive study of trout Sertoli cells and germ cells in primary culture.

\section{MATERIALS AND METHODS}

\section{Animals}

Males of summer-spawning, autumn-spawning, and spring-spawning strains of rainbow trout were used. They were kept in recycled freshwater at $12-15^{\circ} \mathrm{C}$ under natural photoperiod.

\section{Enzymatic Preparation of Testis Cell Suspensions, Cell Separation, and Culture}

All operations were carried out in sterile conditions at $12^{\circ} \mathrm{C}$. Modified L-15 Leibovitz medium ( $\mathrm{pH} \mathrm{7.7;} \mathrm{[Loir,} \mathrm{1988])} \mathrm{was} \mathrm{used} \mathrm{routinely} \mathrm{except} \mathrm{for} \mathrm{testis} \mathrm{dissocia-}$ tion.

The technique used to prepare testis cell populations and to culture them during several days has been described in detail elsewhere [Loir, 1988]. In brief, dissociation of a testis was achieved by perfusion during $5-6 \mathrm{hr}$ with a collagenase plus pronase solution in Swim S77 medium. Most of the spermatozoa were removed (reduction by about 500 times) by centrifugation after mixing with an isotonic Percoll solution (resulting mean density: $1.065 \mathrm{~g} / \mathrm{ml}$ ). The resulting cell suspension ("round testis cell suspension") contained somatic cells and, according to the testis, variable numbers of round germ cells and spermatozoa. This suspension was fractionated into a "single-cell" population and a "cell-cluster" population. Each of them was fractionated into three populations by isopyknic centrifugation in Percoll gradients ("single-cell" populations were numbered 1-3; "cell-cluster" populations were numbered 4-6). In terms of somatic cell composition, populations 1 and 4 were enriched with interstitial cells (Leydig cells and fibroblast / myoid cells). Contamination by Sertoli cells was always $\leq 6 \%$; macrophages were present in population 1 . Round germ cells were present, mainly in population 1 , in variable numbers according to the testes. Populations 3 and 6 were enriched with Sertoli cells. Contamination of population 6 by interstitial cells was always $\leq 5 \%$, and by Leydig cells, it was around $1-3 \%$ or even far lower. Population 6 also contained spermatogonia ( 1 for 
4-5 Sertoli cells) and some spermatozoa ( $\leq 7$ for 1 Sertoli cell; in culture, they underwent destruction and were progressively removed at every change of medium).

Routinely, cells were cultured in plastic multiwell plates either coated with fibronectin [Imbenotte et al., 1985] or uncoated. In this latter case, the cells were usually maintained in suspension. The culture medium was supplemented with $2 \%$ Ultroser (steroid-free serum substitute, IBF, France). Highly purified salmon gonadotropin (s-GtH; [Breton et al., 1978]) was either added or not in the range 0-180 ng/ml.

A total of 36 experiments was run for this study (two to eight experiments for each of the nine maturation stages, determined according to Billard and Escaffre, [1975]).

\section{Mechanical Preparation of Germ Cells}

All the operations were carried out in sterile conditions at $12^{\circ} \mathrm{C}$. Routinely, $2 \mathrm{~g}$ testis at maturation stages IV-VI were cut into small pieces in $20 \mathrm{ml} 1 \%$ BSA in L-15 medium plus $0.1 \%$ Soybean trypsin inhibitor. After filtration on a $150 \mu \mathrm{m}$ nylon filter, the suspension was diluted to $50 \mathrm{ml}$ and, after cell count, aliquots were centrifuged at 200 g. Pellets washed once more in $1 \%$ BSA were resuspended in culture medium. They were either seeded alone in culture or added to cultures of either round testis cells or Sertoli cell-enriched populations.

\section{Preparation of Trout Serum and Lipoproteins}

Trout serum was prepared in a classical way from juvenile animals $(50-120 \mathrm{~g})$ because plasmatic steroid and $\mathrm{GtH}$ concentrations are very low at this age. Total trout lipoproteins were prepared from males at the same maturation stage as those used to prepare the testis cells (stage V or VI). They were prepared by a first centrifugation at $150,000 \mathrm{~g}$ during $40 \mathrm{~h}$ at $10^{\circ} \mathrm{C}$ after the density of serum has been raised to $1.21 \mathrm{~g} / \mathrm{ml}$ [Fremont and Marion, 1982] followed by a second one in the same conditions. The lipoprotein fraction was dialyzed at $4^{\circ} \mathrm{C}$ against $0.15 \mathrm{~m} \mathrm{NaCl}$, then against culture medium, and finally stored at $4^{\circ} \mathrm{C}$. It was used less than 3 weeks after its preparation. Antibiotics were present throughout preparation and storage. The protein concentration was determined according to Fremont and Marion [1982]. After electrophoretic analyses, around $50 \%$ of the obtained lipoproteins were HDL. They contained negligible amounts of steroids and GtH. The concentrations used were 125, 250, and $500 \mu \mathrm{g}$ (lipo)proteins/ml culture medium. They correspond, respectively, to about 1.25, 2.5, and $5 \%$ trout serum.

\section{Cell Identification, Counting, and Viability}

Criteria for the identification of spermatogonia, spermatocytes (cells and nuclei), and Sertoli cells have been given elsewhere [Iatrou et al., 1978; Loir, 1988]. Sertoli cell and interstitial cell nuclei were prepared after cell separation. Sertoli cell nuclei were often ovoid with a central nucleolus, whereas Leydig cell and fibroblast/myoid cell nuclei were usually elongated.

Nuclei of cells either in suspension or spread onto plastic were prepared with $0.4 \%$ hexadecyltrimethylammonium bromide (HTAB; [Loir and Wyrobek, 1972]). Cells in suspension and nuclei were counted using a hemocytometer on a phase-contrast microscope.

Cell viability was checked using several criteria simultaneously or non-simultaneously. Membrane integrity was assayed by the $0.2 \%$ erythrosin B dye exclusion test 
[Phillips, 1973]. Cell morphology, refringence, and ultrastructure were considered as well as the ability of germ cells to gather into clusters during culture. Motility of early spermatid flagella was taken as indicative of a good functional state of these cells. Indeed, in the testis environment, the flagellum of these cells moves slowly, spontaneously, and for a long time.

At the end of culture, the cells were fixed during 10 min with $2 \%$ glutaraldehyde in culture medium, then stained with $0.1 \%$ toluidine blue in $\mathrm{pH} 4.1$ acetate buffer.

\section{Incorporation of $\left[{ }^{3} \mathrm{H}\right]$ Thymidine}

At various times throughout culture and $24 \mathrm{hr}$ before the cells were harvested, 8 $\mu \mathrm{Ci}$ of $\left[{ }^{3} \mathrm{H}\right]$ thymidine (spec. act.: $0.92 \mathrm{TBQ} / \mathrm{mmole}$ ) was added per $\mathrm{ml}$ culture medium. When incubation was stopped, culture medium was removed. As many as possible germ cells (spermatogonia and meiotic cells-spermatocytes and spermatids) were removed by treatment with $\mathrm{Ca}++, \mathrm{Mg}++$-free (CMF) Earle $+1 \mathrm{~mm}$ EDTA and repeated pipetting of the medium, this step being repeated three times. Spread cells were left for two periods of $1.5 \mathrm{hr}$ with new culture medium. Germ cells were centrifuged $(150 \mathrm{~g}, 7$ $\mathrm{min}$ ), then resuspended in new culture medium twice for $1.5 \mathrm{hr}$. Spread cell and germ cell nuclei were then prepared, each with $1 \mathrm{ml}$ HTAB solution, then counted. Nuclei were collected by filtration on GF/C Whatman filters, washed with $10 \mathrm{ml} 5 \%$ perchloric acid, and $10 \mathrm{ml}$ ethanol. Filters were dried, then counted in $4 \mathrm{ml} \mathrm{OCS} \mathrm{(Amersham)}$ scintillator in a Packard Tricarb counter.

\section{Electron Microscopy}

Cells in suspension or attached to plastic were fixed during $30 \mathrm{~min}$ in $2.5 \%$ glutaraldehyde in $0.1 \mathrm{~m}$ cacodylate buffer, $\mathrm{pH} 7.4$, containing $5 \mathrm{~mm} \mathrm{CaCl}_{2}$, then postfixed in $1 \%$ osmium tetroxide in the same buffer containing $1.5 \%$ potassium ferricyanide and $1 \%$ sucrose. The cells were then embedded as described elsewhere [Loir, 1988]. For scanning electron microscopy, the cells attached to plastic were fixed in the same way as above. They were then dehydrated in ethanol, critical-point dried, and coated with gold before being observed.

Some testes at various maturation stages were fixed by vascular perfusion by the testicular vein with $5 \%$ glutaraldehyde in the same buffer as above. Tissue blocks were postfixed, washed, and embedded in the same way as were the cells.

\section{RESULTS}

\section{Sertoli Cells}

Morphology and ultrastructure after testis dissociation. Sertoli cells prepared from testes at maturation stages II, III, and VI-IX were obtained as single cells and in clusters. Although they have a rather compact cytoplasm at stages II-VI, they were highly vacuolated at stages VII-IX and appeared as bubbled cells. The vacuoles were not a consequence of the enzymatic dissociation. Indeed, 1) they sometimes contained either spermatogonia or spermatozoa, and 2) after fixation of mature testes, by perfusion for electron microscopy, it was observed that Sertoli cells had, in situ, such an organization (Fig. 1a). Whatever the maturation stage was, the dissociated Sertoli cells always contained some spermatogonia enclosed in their cytoplasm. At stages VIII-III, a variable number of spermatozoa at various stages of degradation were inserted in Sertoli cells. 

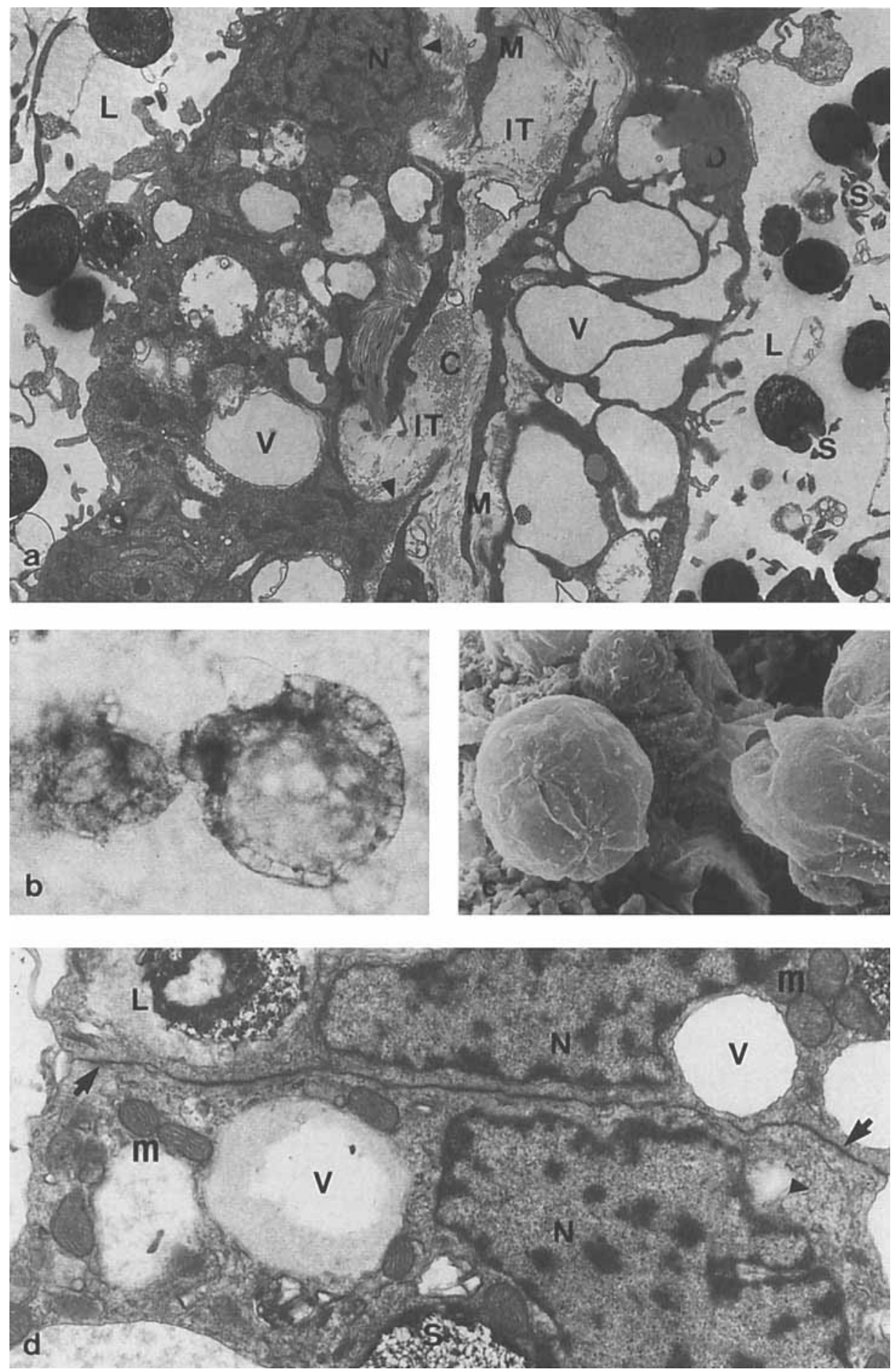

Fig. 1. Trout Sertoli cells (stage VIIIa), in situ (a) and after enzymatic dissociation (b-d). a: Two neighboring lobules separated by interstitial tissue (IT). The Sertoli cells that fringe the lobules are vacuolated (V) - especially those in the right lobule-and they contain some lipid droplets (D). M: myoid cell; C: collagen fibers; N: Sertoli cell nucleus; L: lumen of the lobules; S: spermatozoa; arrowheads: basal lamina. $\times 4,500$. b: Spherical Sertoli cell cluster, which might correspond to an empty cyst having closed back; 4 days in culture. $\times 1,000$. c: idem; scanning electron microscopy. $\times 920$. d: Two adjacent Sertoli cells bound by tight junctions (arrows). N: nuclei; m: mitochondria; L: lysosome with remnants of a sperm nucleus; V: vacuoles; S: decondensed sperm nucleus; arrowhead: SER. $\times 10,400$. 
At stages IV and V, various amounts of Sertoli cells were obtained as closed cysts containing either spermatocytes or spermatids or spermatozoa. Such cysts had a higher buoyant density $(1.045-1.053 \mathrm{~g} / \mathrm{ml})$ than did Sertoli cells devoid of germ cells (1.016$1.045 \mathrm{~g} / \mathrm{ml}$ ), and this reduced the possibility of separating them from the interstitial cell clusters (buoyant density: $1.030-1.060 \mathrm{~g} / \mathrm{ml}$ [Loir, 1988]). With more mature testes, a very low proportion of Sertoli cells was obtained as cysts containing spermatozoa. At stages VII and VIII, some Sertoli cell clusters, corresponding most likely to open cysts, had a tendency to round up and to close (Fig. 1b,c) in suspension.

Apart from the presence or absence of large vacuoles, the ultrastructural features of Sertoli cells (Fig. 1d) did not show obvious variations as a function of the maturation stage. Mitochondria were either oval or spherical. The cristae were mostly lamellar (Fig. 1d) and embedded in a matrix of great density. Exceptionally tubular cristae were observed. Vesicular and tubular smooth endoplasmic reticulum (SER) was more or less abundant and mixed with rough reticulum and free ribosomes. Large osmiophilic bodies devoid of a membrane, but sometimes associated with SER and mitochondria, were scattered in the cytoplasm. They probably corresponded to lipid inclusions. Large secondary lysosomal-like structures, often containing spermatozoa remnants, were present at stages VIII-IV (Fig. 1d).

When in clusters, Sertoli cells at every maturation stage were bound by junctional complexes constituted by typical desmosomes connected to cytoplasmic tonofilaments and by tight junctions (Fig. 1d). Usually, these complexes were located in the apical and basolateral regions of Sertoli cell contacts.

Factors influencing Sertoli cell adhesion in culture. In the absence of added proteins in the culture medium, Sertoli cells adhered to plastic either slowly, if they were in clusters, or hardly if they were as single cells and they began to detach as early as 4 days after. When plastic was coated with fibronectin, all Sertoli cells had adhered after $1.5-20 \mathrm{hr}$ (depending on animals and experiments). In this case, the presence of Ultroser ( 2 or $3 \%$ ), trout serum ( $5 \%$ ), or total lipoproteins $(125 \mu \mathrm{g}$ protein $/ \mathrm{ml}$ ) was not necessary, but these additives speeded up adhesion and spreading. In the presence of serum, Sertoli cells cultured in suspension retained their adhesiveness for 2.5 days, whereas in the presence of $2 \%$ Ultroser, they were non-adhesive after 1 day.

Morphological and ultrastructural changes in culture. When cultured onto fibronectin-coated plastic in the presence of $2 \%$ Ultroser, Sertoli cells spread rather slowly, especially when they were in clusters $\left(0.4 \times 10^{6}\right.$ Sertoli cells $/ \mathrm{cm}^{2}$ needed about 10 days to cover all the area). When spread, they displayed a characteristic epithelioid morphology. When prepared from testes at stages VII-IX, they kept a bubbled appearance for several days (Fig. 2a). In the absence of $\mathrm{GtH}$, the Sertoli cells (mixed with interstitial cells; round testis cell suspension) flattened more rapidly, remained bubbled a longer time, and were less stainable by Toluidine blue than when GtH was present.

After 7-9 days in culture onto fibronectin-coated plastic, a small proportion of flattened Sertoli cells were observed to be dividing (Fig. 2a). Single Sertoli cell and Sertoli cell cluster populations incorporated $\left[{ }^{3} \mathrm{H}\right]$ thymidine as early as $3-4$ days in culture (Fig. 3). Incorporated amounts increased with the culture duration. During the same period, the number of germ cells either adhering to or enclosed in the Sertoli cells decreased (see below). So the incorporation of $\left[{ }^{3} \mathrm{H}\right]$ thymidine by germ cells contributed progressively less to the apparent incorporation by Sertoli cells. At least at stage $\mathrm{V}$, the 

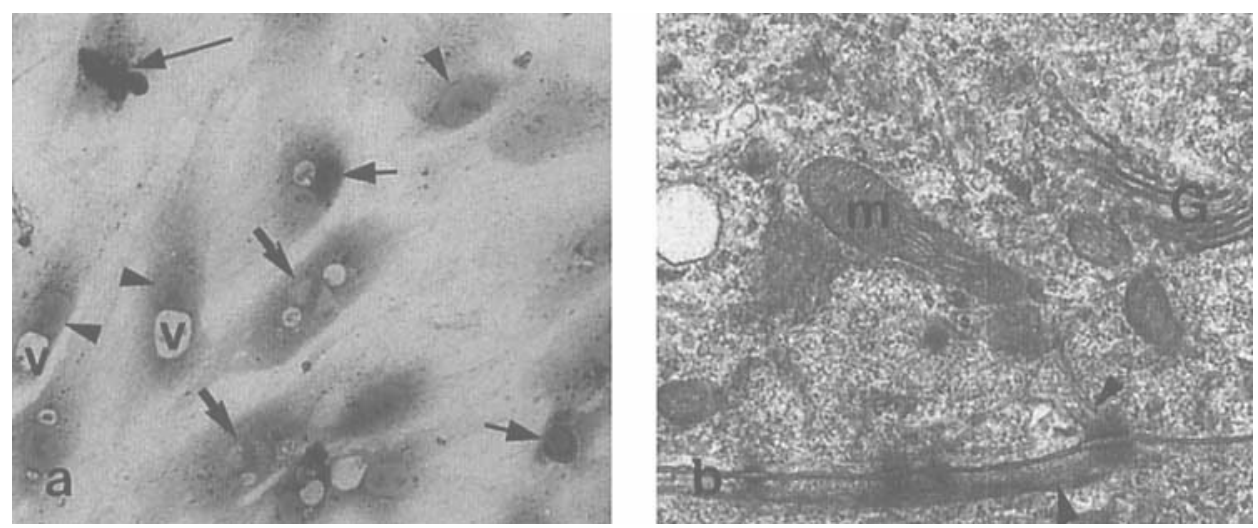

Fig. 2. Sertoli cells in culture. a: Stage VIIIa testis. Ten days in culture. Sertoli cell cluster population. Toluidine blue staining. In this area, Sertoli cells are in a monolayer. Large arrows: two Sertoli cells are dividing, the nuclei being in metaphase. No vacuole is visible in several Sertoli cells (top, right). In others, a large vacuole (V) is still present in contact with the nucleus (arrowheads). Two spermatogonia (short thin arrows) are still enclosed in Sertoli cells. Some germ cells (long thin arrow) adhere to a Sertoli cell. $\times 430$. b: Stage IV testis. Nine days in culture. Desmosomes and tight junctions between two Sertoli cells. G: golgi; $\mathrm{m}$ : mitochondria; arrowheads: tonofilaments. $\times 26,000$.

$\left[{ }^{3} \mathrm{H}\right]$ thymidine incorporation was not significantly sensitive to $\mathrm{GtH}$ after 7.5 and 10 days in culture.

After electron microscopy, whether the Sertoli cells (mixed with interstitial cells or alone; in the presence of $100 \mathrm{ng} \mathrm{GtH} / \mathrm{ml}$ ) were cultured as clusters onto plastic or in suspension, their ultrastructure was not obviously changed in most of the experiments, for at least 13 days. Notably, junctional complexes were always present (Fig. 2b; fig. 4 in [Loir, 1988]). However, Sertoli cells from testes at stages VII-IX became progressively less vacuolated and they recovered a compact organization (Fig. 4a) similar to that of Sertoli cells observed in testes resuming spermatogenesis (stage II). This recovery was speeded up by lipoproteins ( 125 or $500 \mu \mathrm{g} / \mathrm{ml}$ ). Notably, after 2.5 days in their presence, the cytoplasm of the Sertoli cells - as compared with those cultured with Ultroser only (Fig. 4b,c)-was better organized: it contained fewer vacuoles and lysosomal-like structures containing less debris and more smooth endoplasmic reticulum was visible.

\section{Spermatogonia}

After enzymatic dissociation of testes. Spermatogonia were obtained either as isolated cells or included in Sertoli cells. Especially with testes at maturation stage II or III, we have frequently observed one large A spermatogonium enclosed in one Sertoli cell. With mature testes, only a low number of spermatogonia (usually one, exceptionally 2 or 3) was observed enclosed in a sertolian "vacuole." In Sertoli cell cluster populations, there was a mean of one spermatogonium for two to six Sertoli cells. The cytoplasm of the spermatogonia, especially those of the A type, was clearer than that of Sertoli cells although it was rich in free ribosomes. Endoplasmic reticulum was usually reduced. Mitochondria were numerous; they had a clear matrix and some scarce lamellar cristae.

The buoyant density determined after centrifugation into Percoll gradients was between 1.045 and $1.070 \mathrm{~g} / \mathrm{cm}^{3}$ with a mean value of $1.055 \pm 0.003 \mathrm{~g} / \mathrm{cm}^{3}(\mathrm{n}=7)$.

Changes in culture. The behaviour of spermatogonia differed conspicuously from that of the other germ cells (see below). Indeed, after electron microscopy they were not 


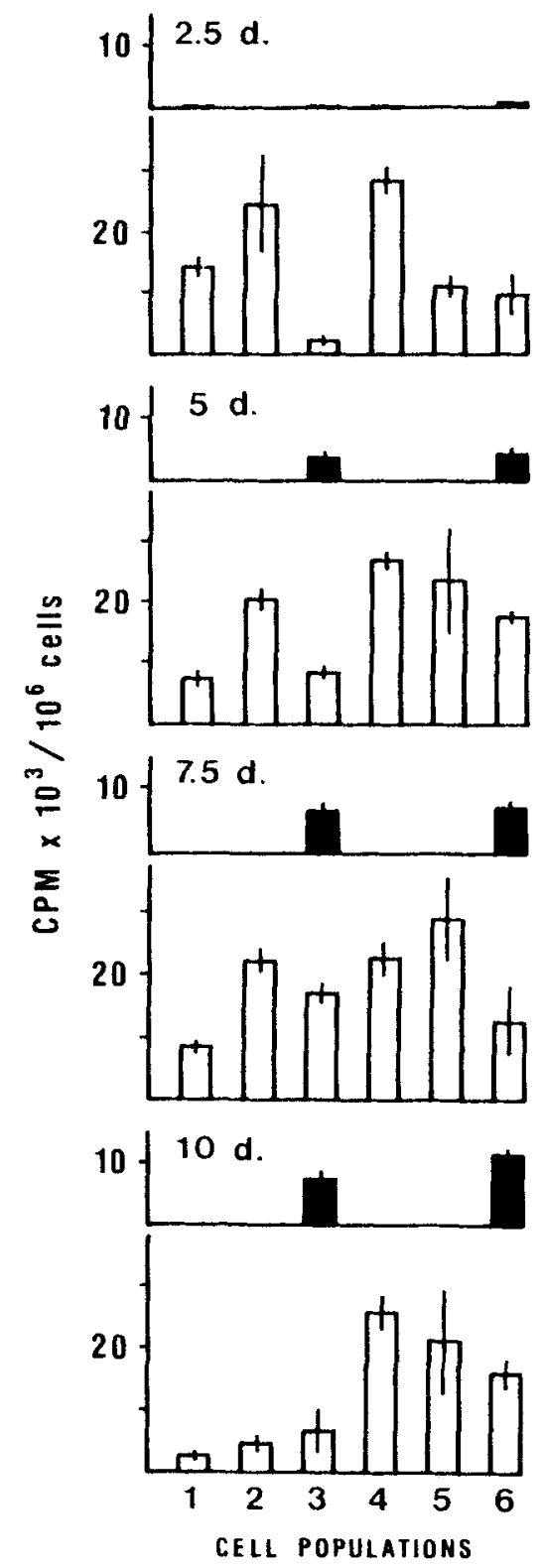

Fig. 3. Incorporation of $\left[{ }^{3} \mathrm{H}\right]$ thymidine $\left(\mathrm{cpm} / 10^{6}\right.$ cells, mean $\pm \mathrm{SE}$, three wells) by the Sertoli cell-enriched populations 3 and 6 (cells attached to plastic; hatched bars) and by the spermatogonia (free cells and cells detached from Sertoli cells; white bars) present in the six cell populations obtained after Percoll gradient centrifugation and cultured during 2.5, 5, 7.5, and 10 days. Stage VIIIa testis. Cell populations 1-3: single-cell populations. Populations 4-6: cell cluster populations. Populations 1 and 4: interstitial cell-enriched populations (93 and $95 \%$ of the somatic cells; one spermatogonium per two and 26 interstitial cells, respectively). Populations 3 and 6: Sertoli cell-enriched populations (97 and 98\% of the somatic cells; one spermatogonium per 2.4 and three Sertoli cells, respectively). Populations 2 and 5: mixed populations. 

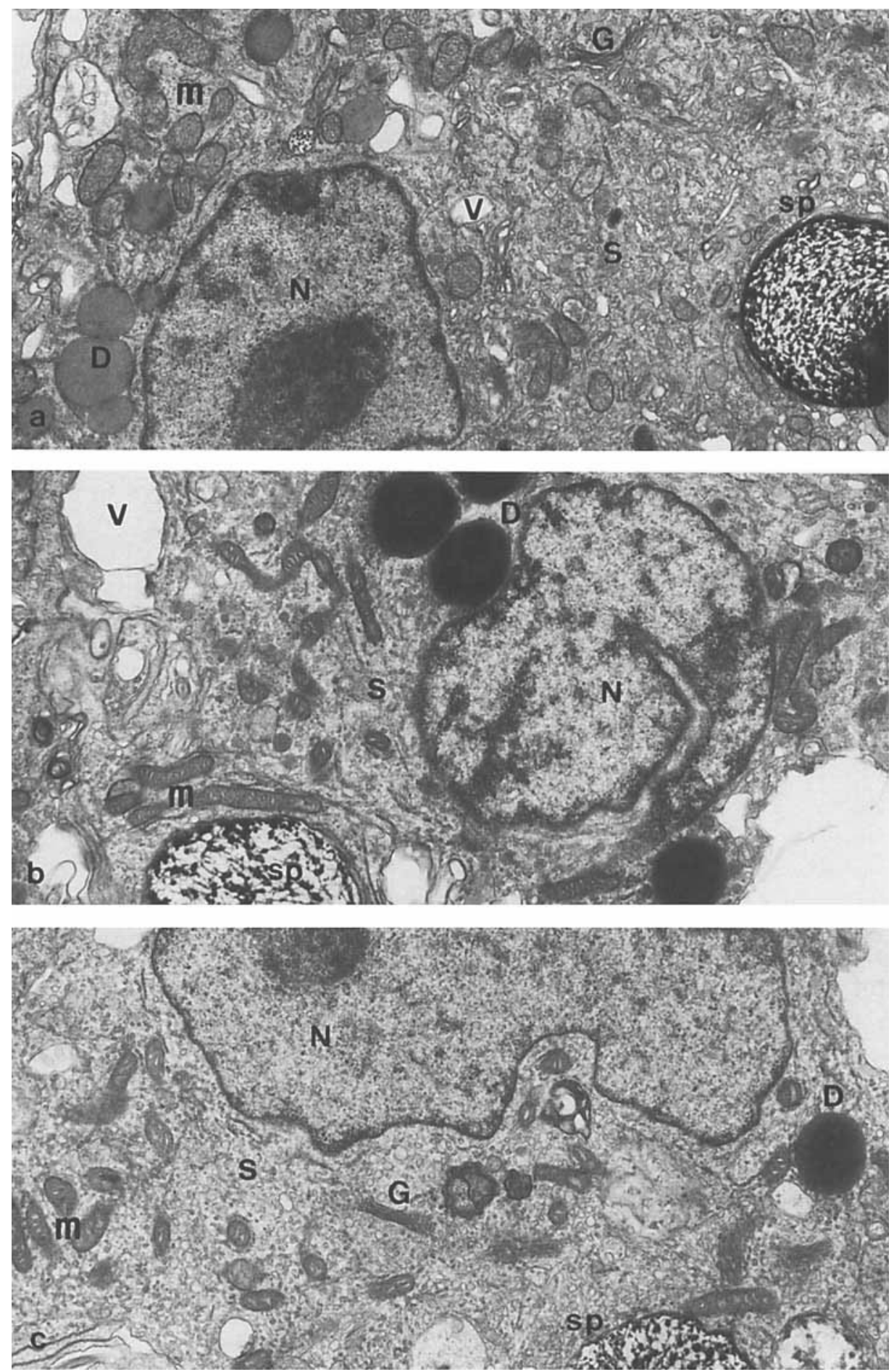

Fig. 4. Sertoli cells in culture. a: Stage VIIla testis. Nine days in culture in the presence of 3\% Ultroser. Only some small vacuoles are still present in the cytoplasm. $\times 11,200$. b: Stage $V$ testis. Two and one-half days in culture in the presence of $2 \%$ Ultroser. The Sertoli cell cytoplasm is somewhat disorganized. $\times 10,400$. c: Stage $V$ testis. 2.5 days in culture in the presence of $500 \mu \mathrm{g}$ (lipo)proteins $/ \mathrm{ml}$, in addition to Ultroser. The Sertoli cell cytoplasm is well organized and contains an abundant SER. $\times 10,900$. N: nucleus; m: mitochondria; G: golg; S: SER; D: lipid droplets; SP: decondensed sperm nucleus; V: vacuoles. 
affected by the enzymatic treatment and the medium used to culture testis somatic cells was suitable for them. They were able to survive for at least 15 days whether they were free in suspension in the presence of Sertoli cell-enriched populations or adhered onto these cells.

In culture, the free spermatogonia showed a tendency to coalesce to form clusters. After cell counting between slide and coverslip (Fig. 5a), one cluster contained, after 9 days in culture, approximately 1,100 cells, $95 \%$ of which were A and B spermatogonia, whereas most of the others were young spermatocytes. In such clusters, the cells were bound by small desmosome-like junctions similar to those observed between Sertoli cells and germ cells (see below) and which were especially apparent at both ends of the cell contact (Fig. 5b). In addition, some cytoplasmic bridges were present between spermatogonia (in situ, they exist between B spermatogonia).

After 5 days in culture, some spermatogonia undergoing mitosis were observed (electron microscopy) in free clusters as well as among those enclosed in Sertoli cells
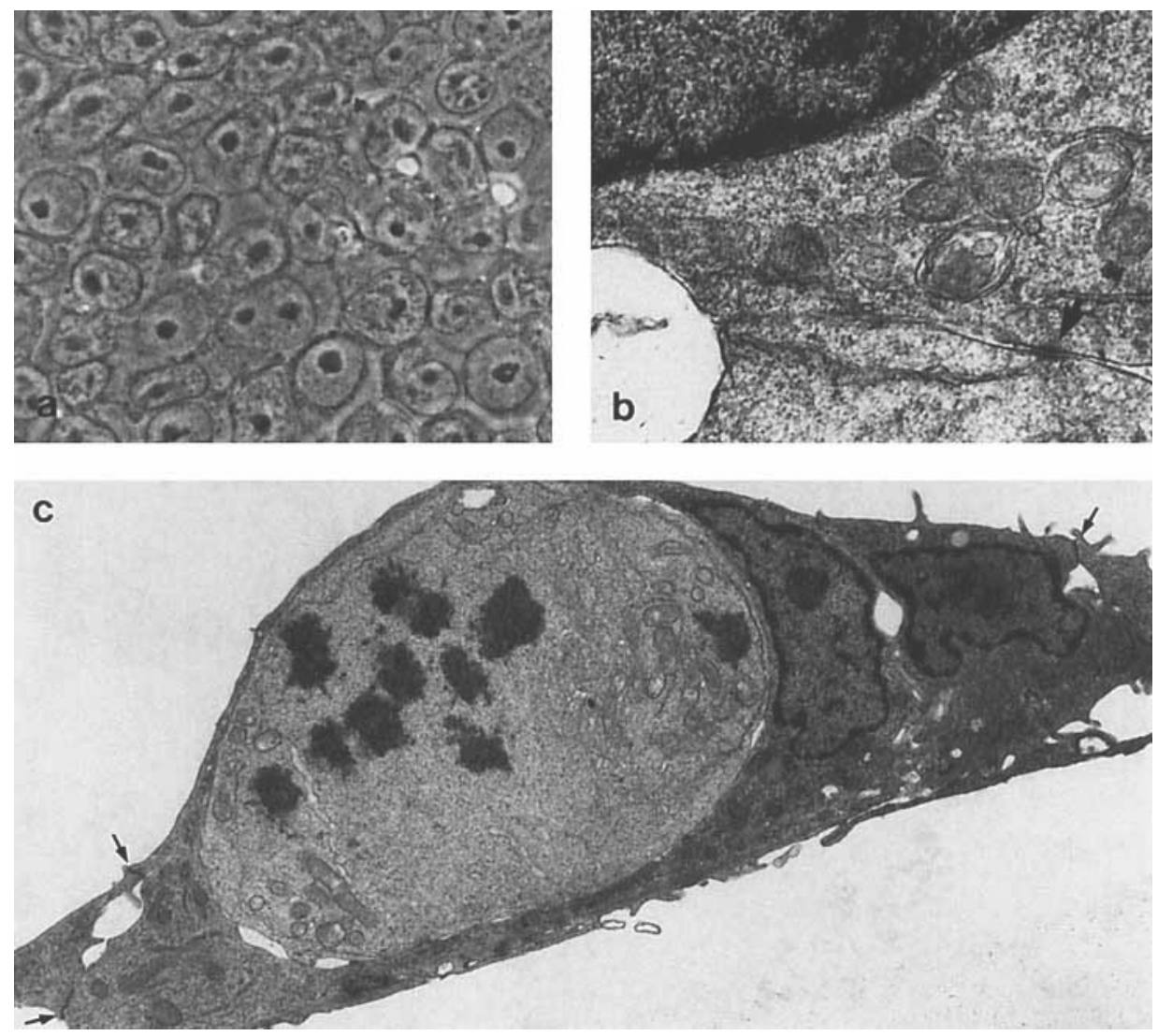

Fig. 5. Spermatogonia in culture. a: Stage VIIIa testis. Nine days in culture. A cluster squashed between slide and coverslip. Phase contrast microscopy. Most of the nuclei are spermatogonia nuclei. $\times 785$. b: Stage IV testis. Twelve days in culture. Desmosome-like junction (arrow) between two spermatogonia. $\times 28,000$. c: Stage IV testis. Nine days in culture. A spermatogonium in mitosis enclosed in a spread Sertoli cell. Arrows: tight junctions between neighboring Sertoli cells. $\times 5,100$. 
(Fig. 5c). We measured the incorporation of $\left[{ }^{3} \mathrm{H}\right]$ thymidine (Fig. 3) by the spermatogonia present (and the some preleptotene-leptotene spermatocytes also present, mainly in the three single-cell populations) in the six different cell populations obtained after Percoll gradient centrifugation and cultured during 10 days (maturation stage VIII). The mean values of $\left[{ }^{3} \mathrm{H}\right]$ thymidine incorporation by spermatogonia in the three singlecell populations and by those in the three-cell cluster populations differed only slightly during the first 7.5 days. At 10 days, the incorporation by the single-cell populations was reduced. It is worth noting that spermatogonia present in the interstitial cell clusterenriched population (population 4, Fig. 3) always incorporated more $\left[{ }^{3} \mathrm{H}\right]$ thymidine than did those present in the Sertoli cell-enriched populations 3 and 6. At maturation stage VIII (two experiments), the incorporation of $\left[{ }^{3} \mathrm{H}\right]$ thymidine by spermatogonia cultured in the presence of somatic testicular cells was significantly increased by $20 \mathrm{ng}$ $\mathrm{GtH} / \mathrm{ml}$ after 5 days (stimulated/basal $=1.6$ ) and after 7.5 days (stimulated/ basal $=1.3$ ) in culture. At 10 days, GtH had no effect on DNA synthesis.

\section{Spermatocytes and Spermatids}

Morphology and ultrastructure after preparation. After dissociation of testes with collagenase and pronase, the viability of these cells, as checked by the exclusion dye test, was above $90 \%$. However, the electron density of chromatin was increased in most of the spermatocytes and spermatids as compared with the in situ nuclei.

After mechanical preparation, the ultrastructure of the spermatocytes and spermatids was similar to that observed in situ and the viability of these cells was also above $90 \%$. Whether spermatocytes and spermatids were prepared mechanically or enzymatically, most of them were obtained as individual cells but with some obtained as multinucleated giant cells (symplasts, [Romrell et al., 1976]; Fig. 6a). Such symplasts resulted from the widening of the cytoplasmic bridges that exist in situ between the cells of a same "clone." We have observed as many as 22 spermatocyte nuclei in a symplast, but most often there were only two to four nuclei.

Survival in culture. Mechanically prepared meiotic germ cells, cultured alone, have been used to choose a culture medium suitable for these cells. At first, a rich and complex medium such as M-199 appeared to be unsuitable, as the meiotic cells did not survive more than 2 days. The seminal fluid mineral medium (SFMM; [Billard, 1983]) that is especially adapted for the survival of spermatozoa has the same effect. Surprisingly, a saline solution such as Earle's was able to sustain these cells alive for a longer period (3-4 days according to the testis). L-15 Leibovitz medium buffered with $10 \mathrm{~mm}$ Hepes at $\mathrm{pH} 7.8$ and adjusted to $300 \mathrm{~m} 0$ smoles has allowed to keep the meiotic germ cells alive during 3-5 days, according to the testis. Na bicarbonate ( $4 \mathrm{~mm})$, which has not been demonstrated to be damaging for testis somatic cells [Loir, 1988], reduced the spermatocyte viability by $5-15 \%$ after 1 day in culture. Ultroser ( 2 or $2.5 \%$ in L15 medium) was necessary to improve cell viability $(40-50 \%$ viable cells with Ultroser vs. $0-5 \%$ without, after 4 days in culture). In the most favorable conditions, some spermatocytes were still viable after 5 days in culture (in the absence of somatic cells) and some scarce spermatid flagella were still motile. Two days later, all the cells were dead.

The viability (Table 1 ) of the meiotic cells (cultured in L15 medium plus $2 \%$ Ultroser) has appeared to be highly dependent on the presence of somatic testicular cells. In their presence, the survival of the meiotic cells was prolonged for several days whatever the method of preparation was, provided they adhered to Sertoli cells. The viability of mechanically prepared meiotic cells was then $85-90 \%$ after 2 days in the 

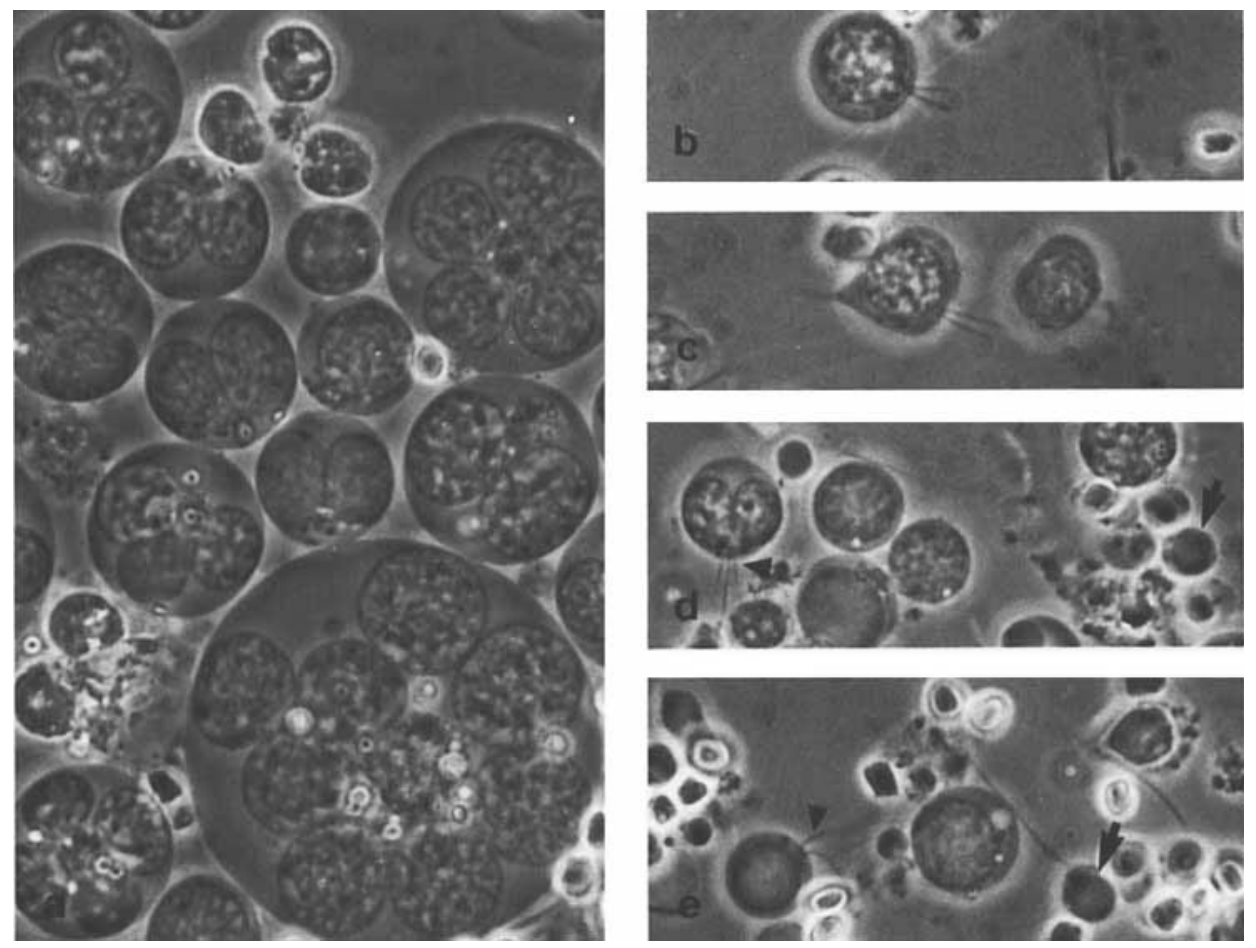

Fig. 6. Meiotic cells after enzymatic preparation (a) and after 3 days in culture in the presence of somatic cells and of lipoproteins (b-e). Stage $V$ testis. Phase-contrast microscopy. a: Spermatocyte symplasts (two to nine nuclei) squashed between slide and coverslip. $\times 1,150$. b: A primary spermatocyte with two short flagella. c: Idem. d: Secondary spermatocyte symplast with four short flagella (only three are visible; arrowhead). e: Secondary spermatocyte-round spermatid with two long motile flagella (arrowhead). b-e: $\times 1,050$. Arrows: round spermatids.

presence of somatic cells, vs. $45-65 \%$ when they were alone. Some spermatocytes $(5-35 \%)$ were still viable after 10-12 days in culture, whereas all the free ones were dead.

After 7.5 days in the presence of either $5 \%$ serum (Fig. $7 \mathrm{~b}$ ) or total trout lipoproteins (125 or $500 \mu \mathrm{g}$ protein $/ \mathrm{ml}$; Fig. $7 \mathrm{c}$ ), the spermatocytes and spermatids adhering to Sertoli cells were spherical and had a well-preserved ultrastructure. In the presence of Ultroser only, they were flattened and had a rather polygonal shape (Fig. 7a). In the presence of lipoproteins, 80-93\% of the spermatocytes that still adhered to the Sertoli cells were viable after 10 days in culture. In addition, motile flagella were observed for 2-3 days longer in the presence of either lipoproteins or serum than in the presence of $2 \%$ Ultroser alone: 10 days vs. 7 days with a stage $V$ testis, 7 days vs. 5 with another stage V testis, and 5 days vs. 3 with a stages VI--VII testis.

Differentiation in culture. First meiotic divisions, and some divisions thought to be second meiotic ones, were regularly observed during culture of enzymatically or mechanically prepared germ cells, in the presence of somatic testicular cells. On the other hand, as early as 2.5 days, germ cells were observed with two motile flagella the lengths of which were about that of the tail of a spermatozoa or a little shorter. The nuclear volume 
TABLE 1. Viability of Spermatocytes

\begin{tabular}{lccccc} 
& \multicolumn{2}{c}{ Mechanically prepared cells } & & \multicolumn{2}{c}{ Enzymatically prepared cells } \\
\cline { 2 - 3 } \cline { 5 - 6 } & Alone (\%) & +Somatic cells (\%) & & Alone (\%) & +Somatic cells (\%) \\
\hline After preparation & $90-97$ & & $90-95$ & \\
After 2 days & $45-65$ & $85-90$ & & \\
After 5 days & $5-20$ & $60-80$ & 0 & \\
After 10 days & 0 & $5-35$ (AC) & 0 & $80-93$ \\
& & 0 (FC) & & (LP present) \\
\hline
\end{tabular}

Viability (erythrosin dye test completed in some cases by ultrastructural observations) of spermatocytes (identified by their size and when possible by their appearance in phase-contrast microscopy) either mechanically or enzymatically prepared (maturation stages: III-VI) and cultured in L15 medium plus $2 \%$ Ultroser, either in the absence or in the presence of somatic testicular cells (stages III-VIIIa). At least two experiments per datum. LP: trout lipoproteins. AC: cells adhering to Sertoli cells. FC: cells free in the medium.

was intermediate between that of a spermatocyte I and that of a round spermatid. The chromatin had an appearance similar to that of a round spermatid nucleus (Fig. 6e). Some other cells having a spermatocytic-like nucleus had four short $(3-6 \mu \mathrm{m})$ unmotile flagella (Fig. 6d) or more rarely only two such flagella (Fig. 6b,c).

\section{Interactions Between Sertoli Cells and Germ Cells}

Whether germ cells were mechanically or enzymatically prepared, they scarcely adhered to fibronectin-coated plastic and to the surface of spread fibroblastoid cells (Leydig and fibroblast/myoid cells) (Fig. 8a,b). On the contrary, large numbers of germ cells adhered to the surface of spread Sertoli cells until completely covering some areas. In fact, this was true for spermatogonia and spermatocytes as only a low proportion of spermatids adhered to Sertoli cells. Mechanically prepared germ cells from stage V testes were able to adhere to spread Sertoli cells prepared from stage VIII testes. Red blood cells did not adhere to Sertoli cells.

The presence of $5 \%$ trout serum (three experiments) or more especially of total trout lipoproteins (two experiments) favored constantly the adhesion of germ cells to Sertoli cells. In the presence of $500 \mu \mathrm{g}$ (lipo)protein $/ \mathrm{ml}, 1.5-2$ times more germ cells were fixed to the same number of Sertoli cells after 2.5 and 7.5 days in culture. It was also observed that $100 \mathrm{ng} \mathrm{s}-\mathrm{GtH} / \mathrm{ml}$ (one experiment with a round testis cell population) increased the number of germ cells adhering after 2.5 and 7.5 days in culture to the same number of Sertoli cells by 1.8 and 1.6 times, respectively. This effect was additive to that provided by lipoproteins.

After several days in culture, although the Sertoli cells became extremely flattened, fewer and fewer germ cells remained fixed onto them (Figs. 2a, 8b). This was also true for the spermatogonia previously included in Sertoli cells.

Treatment with $0.25 \%$ trypsin in Earle at $12^{\circ} \mathrm{C}$ for a few minutes led to the detachment of the germ cells from Sertoli cells (but also in the same time these latter cells began to round up and to detach). Removal of $\mathrm{Ca}++$ and $\mathrm{Mg}++(\mathrm{CMF}$ Earle plus $1 \mathrm{~mm}$ EDTA) had a more discrete effect.

After transmission electron microscopy, spermatocytes were bound to Sertoli cells by discrete desmosome-like junctions (Fig. 8c) and by some scarce sertolian laminar protrusions. Although spermatogonia included in Sertoli cells were completely surrounded by them, similar junctions occurred between both cells (Fig. $8 \mathrm{~d}$ ). In situ, some 

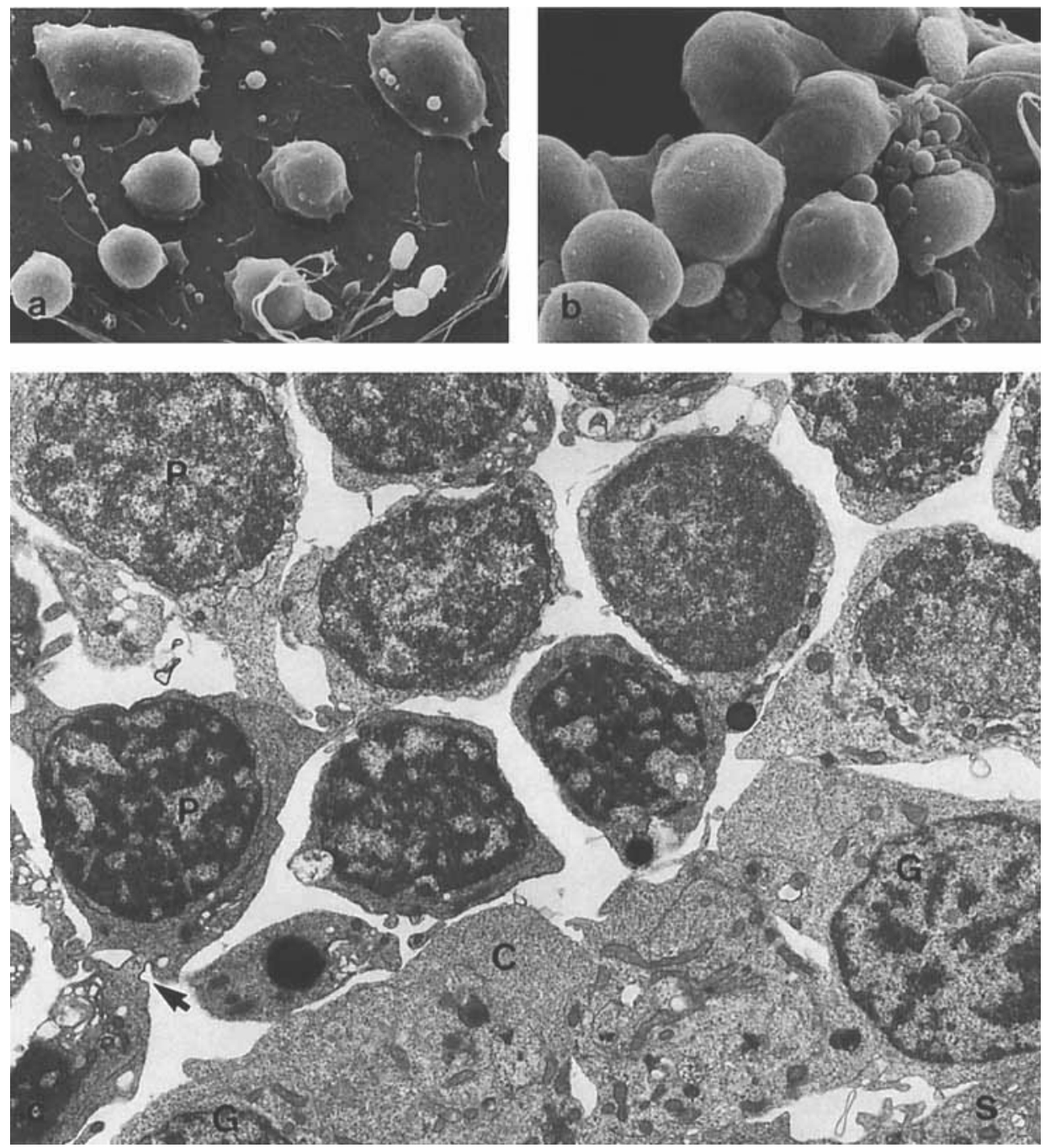

Fig. 7. Germ cells fixed onto Sertoli cells. a: Stage V testis. Four days in culture in the presence of $2 \%$ Ultroser only. Scanning electron microscopy. $\times 1,800$. b: Idem, plus $5 \%$ young trout serum. $\times 3,200$. c: Stage $\mathrm{V}$ testis. Seven and one-half days in culture in the presence of $500 \mu \mathrm{g}$ (lipo)proteins $/ \mathrm{ml}$. S: Sertoli cell cytoplasm; G: spermatogonium; C: spermatogonial cytoplasm; P: primary spermatocytes; arrow: cytoplasmic bridge. $\times 5,400$.

such junctions have been observed between spermatogonia and spermatocytes on one hand and Sertoli cells on the other.

\section{DISCUSSION}

\section{Sertoli Cells}

After enzymatic dissociation, the ultrastructure of the Sertoli cells did not differ from that observed in situ [Billard et al., 1972; Van den Hurk et al., 1978]. Especially, 

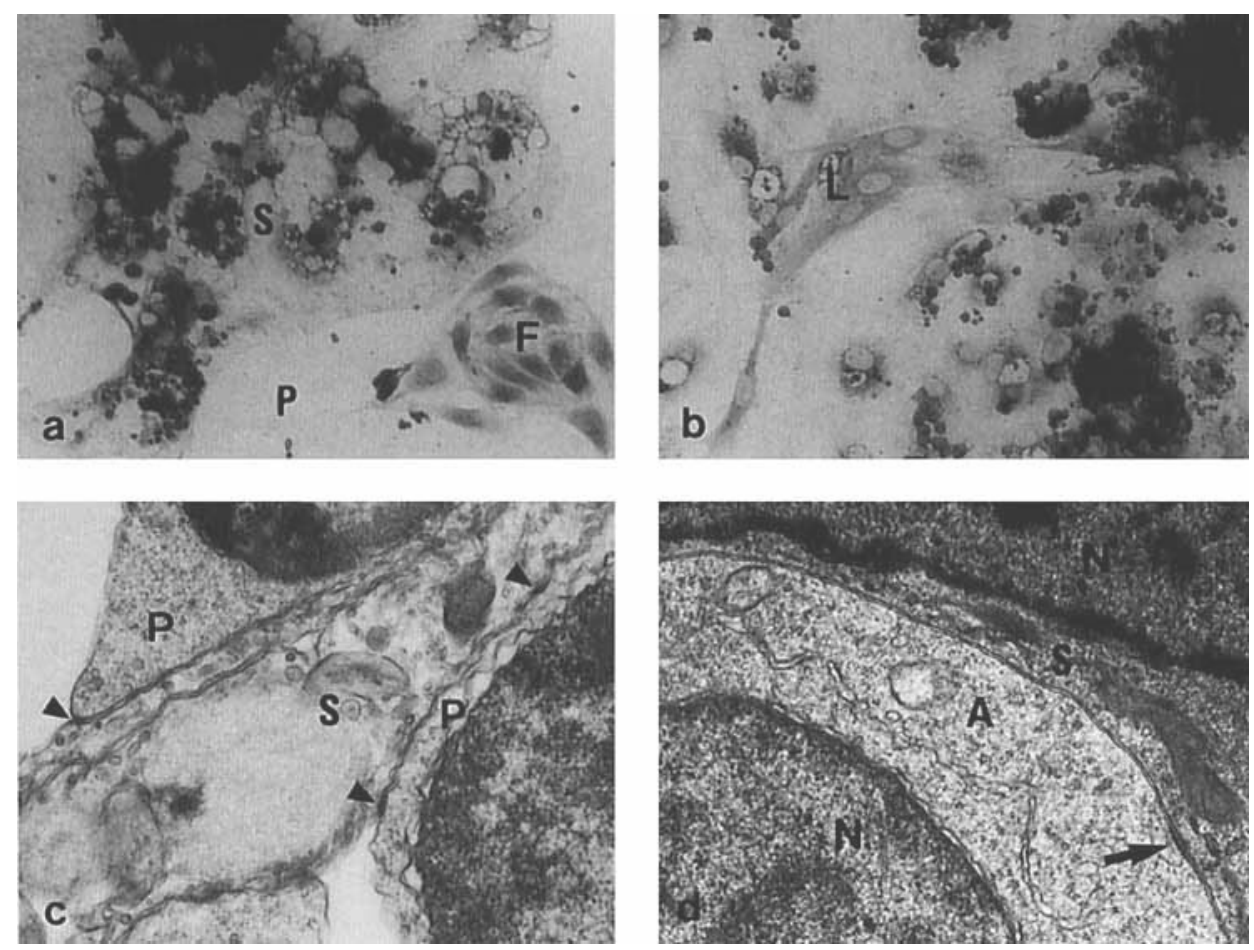

Fig. 8. Adhesiveness of the germ cells in culture. a,b: Stage $V$ testis. Culture in the presence of lipoproteins. Toluidine blue staining. a: 2.5 days in culture. Germ cells (darkly stained) do not adhere onto fibronectincoated plastic (P) and fibroblastoid cells (F) but onto Sertoli cells $(S) . \times 300$. b: 7.5 days in culture. Germ cells are absent on the Leydig cells (L) and the areas where the Sertoli cells are in a flat monolayer (on the left). $\times 300$. c: Stage $V$ testis. Seven and one-half days in culture in the presence of $500 \mu \mathrm{g}$ (lipo)proteins $/ \mathrm{ml}$. Desmosome-like junctions (arrowheads) between two primary spermatocytes (P) and a Sertoli cell (S). $\times 17,500$. d: Stage IV testis. Nine days in culture. Desmosome-like junction (arrow) between an A spermatogonium (A) and the Sertoli cell (S) that surrounds it. N: nuclei. $\times 19,500$.

mitochondrial cristae were rarely observed to be tubular and the SER was always present, being sometimes associated with lipid droplets. These features did not seem to change according to the maturation stage, but this point has not been investigated quantitatively.

Culture of rat Sertoli cells onto a reconstituted membrane gel [Hadley et al., 1985] allows them to keep a columnar morphology and features more characteristic of the in vivo differentiated cells. Neither biomatrix nor matrix components (only fibronectin) have been used for trout Sertoli cells. Nevertheless, some observations suggest that functional differentiation of these cells was retained as long as they were not organized in a thin cell monolayer: 1) The fine ultrastructure of the Sertoli cells in clusters (either in suspension or adhering to plastic) did not display obvious changes during at least 13 days; 2) junctional complexes were always present; and 3) germ cells adhered to the surface of the Sertoli cells and some of them underwent meiosis. On the contrary, the migration and flattening of Sertoli cells is probably related to the loss of some differentiated functions of these cells. This was reflected by the removal of cells previously present on the surface or enclosed in the Sertoli cells. In the rat, Tung and Fritz [1984] have shown that Sertoli 
cells cultured onto an extracellular matrix simultaneously keep a compact shape and remain able to retain germ cells with a normal ultrastructure. On the other hand, some flattened trout Sertoli cells were observed in mitosis. According to Tung and Fritz [1984], flat rat Sertoli cells have higher rates of DNA synthesis than those which, in aggregates, retain a cuboidal shape. After $\left[{ }^{3} \mathrm{H}\right]$ thymidine incorporation, the proliferation of Sertoli cells begun as early as 2.5-4 days in culture, but it remained relatively low until 10 days (as compared to spermatogonia and interstitial cells; not shown). It is to be noted that in Squalus acanthias, Sertoli cells (meiotic and post-meiotic stages) proliferate in vitro when they were in monolayers but not when cultured as intact spermatocysts [Callard et al., 1988].

In vivo, the fate of trout Sertoli cells between spermiation and the spermatogenetic cycle that follows is unknown [Billard, 1986]. Do they degenerate at the time of testis regression as in the guppy? This may be hypothesized as these are probably the Sertoli cells associated with the A spermatogonia that would surround the developing cysts during the next cycle. Do trout Sertoli cells divide when the cysts become larger due to germ cell proliferation, as already demonstrated for Sertoli cells from Squalus acanthias premeiotic testes [Callard et al., 1988]? In any case, our observations show that 1) stages VII-VIII Sertoli cells that were very vacuolated at the time of spermiation were able to recover, in culture, a compact organization similar to that observed during stage II or III, and 2) they were able to divide.

\section{Germ Cells}

Several observations suggest the occurrence of clear-cut differences between spermatogonia and the meiotic germ cells, in response to isolation and to culture conditions. Spermatogonia were not affected by the enzymatic treatment, whereas the density of the chromatin of spermatocytes and spermatids increased. Spermatogonia accepted rich culture media and $4 \mathrm{~mm} \mathrm{Na}$ bicarbonate, whereas meiotic germ cells prefered a less complex medium (L15) without this salt. Spermatogonia were able to survive during at least 15 days without being in contact with Sertoli cells, whereas spermatocytes and spermatids were not. Ultroser was sufficient to maintain survival and ultrastructural integrity of spermatogonia. On the contrary, spermatocytes and spermatids needed either trout serum or trout lipoproteins, in addition to Ultroser, to keep the normal organization of their membranous components. This need for lipoproteins suggests that trout meiotic germ cells are dependent on an exogenous lipid supply. This assumption agrees with the proposal by Fremont and Marion [1982] that trout HDL, which are in great amount in plasma during spermatogenesis, are incorporated in testicular lipids and are utilized for germ cells. On the other hand, it is worth noting that the concentration of $125 \mu \mathrm{g}$ (lipo)proteins/ml that was used corresponded to about $60 \mu \mathrm{g}$ $\mathrm{HDL} / \mathrm{ml}$. This is about the HDL concentration $(70 \mu \mathrm{g} / \mathrm{ml})$ in trout testicular fluid and seminal plasma [Loir and Le Cornet, unpublished].

Stage VIII spermatogonia divided in vitro during at least 10 days. In Xenopus, these cells proliferate in the absence of Sertoli cells during at least 12 days [Risley, 1983]. In the rat, after Tres and Kierszenbaum [1983], spermatogonia were still capable of synchronous cell division 6 days after plating with Sertoli cells. Trout spermatogonia incorporated more $\left[{ }^{3} \mathrm{H}\right]$ thymidine when interstitial cells were present rather than when Sertoli cells were. This suggests that steroids (androgens?) produced by Leydig cells [Le Gac and Loir, 1988] could enhance spermatogonial multiplication and could act as 
mediators for the stimulating effect of GtH. This hypothesis agrees with data obtained by Remacle [1976] in the goldfish on the improving effect of testosterone on germ cell survival and by Schulz and Blüm [1988] who have localized testosterone immunoreactive material in trout spermatogonia.

Some young primary spermatocytes were observed among spermatogonia clusters. This suggests that spermatogonia could progress through divisions to spermatocytes, but this has not been demonstrated. The presence of first and possibly second meiotic divisions indicates that at least some primary spermatocytes differentiated to young spermatids, although this process would be impaired for some cells. Indeed, we interpret the cells with four short flagella and those with two long ones as, respectively, primary and secondary spermatocytes that had not undergone meiotic nuclear division(s). In the newt, when the second meiotic division was inhibited by cycloheximide [Kiyotaka and Abe, 1983], one centriole forms a flagellum. In our case, we suppose that the process of chromosome condensation was impaired for an unknown reason, but not the centriole duplication. Thus, each centriole has formed a flagella as would have occurred normally after completion of the second meiotic division, in the four or two resulting round spermatids. In Xenopus, $90 \%$ of the primary spermatocytes develop into four spermatids each in 21 day cultures [Risley, 1983].

\section{Interactions Between Germ Cells and Somatic Cells}

Trout meiotic cells, as the mammalian ones [Palombi et al, 1979; Tres and Kierszenbaum, 1983], appeared to be highly dependent on Sertoli cells. They differ completely from the amphibian ones that can develop independently of Sertoli cells [Risley, 1983].

The specificity of adhesion between Sertoli cells and spermatogenic cells was demonstrated some years ago in the rat [Tres and Kierszenbaum, 1983]. Our observations suggest that a similar specificity would occur in the trout and would not be maturation stage-dependent. Indeed, germ cells attached only to Sertoli cells and neither to interstitial cells nor to fibronectin-coated plastic. The adhesion of spermatocytes is mediated by scarce discrete desmosome-like junctions identical to those described by Sprando and Russell [1987] in other fish as well as in non-mammalian and mammalian vertebrates. Few spermatids adhered to Sertoli cells, and after processing of the spread cells for electron microscopy, no spermatid was observed. Enders and Millette [1988] have carried out the same observation in mouse, and they have concluded that the junctions formed by spermatids with Sertoli cells are weak, because of either in vitro conditions or of the advanced maturation stage.

Several recent studies have demonstrated that in mammals germ cells might influence the metabolism of Sertoli cells [Le Magueresse and Jégou, 1988]. As no metabolic marker for trout Sertoli cells was identified until recently, we have no information about the occurrence of such a modulating influence in teleosts. An ABP-like activity [Foucher and Le Gac, 1989] and an aromatase activity [Le Gac and Loir, 1988] have been demonstrated to be present in trout testis. On the other hand, trout Sertoli cells produce $17 \alpha-\mathrm{OH}$-progesterone [Le Gac and Loir, 1988]. The study of the possible influence of maturing germ cells on these activities will provide useful information about the local control of fish spermatogenesis. 


\section{ACKNOWLEDGMENTS}

This work was supported in part by a grant from the Institut National de la Recherche Agronomique (AIP 4433). We thank Dr. B. Breton for the kind gift of $\mathrm{s}-\mathrm{GtH}$. We are indebted to Prof. R Folliot for providing electron microscopy facilities. EM was carried out at the Centre Commun de Microscopie Electronique à Transmission de l'Université de Rennes. We are grateful to Mrs. C. Cauty for her skillful assistance in preparing sections for EM, to J.Y. Lefeuvre for excellent assistance in preparing the figures, and to J. Hall for help with the English.

\section{REFERENCES}

Billard R (1983): Effects of coelomic and seminal fluids and various saline diluents on the fertilizing ability of spermatozoa in the rainbow trout, Salmo gairdneri. J Reprod Fertil 68:77-84.

Billard R (1986): Spermatogenesis and spermatology of some teleost fish species. Reprod Nutr Dev 26:877-920.

Billard R, Escaffre AM (1975): Identification des stades de la spermatogenese de la truite fario d'apres la morphologie des gonades et la spermiation. Bull Fr Pisci 256:111-118.

Billard R, Jalabert B, Breton B (1972): Les cellules de Sertoli des poissons téléostéens. I. Etude ultrastructurale. Ann Biol Anim Bioch Biophys 12:19-32.

Breton B, Prunet P, Reinaud P (1978): Sexual differences in salmon gonadotropin. Ann Biol Anim Biochim Biophys 18:759-765.

Callard GV, DuBois W, Givonetti L (1988): Stage-dependent variations in $\left({ }^{3} \mathrm{H}\right)$ thymidine incorporation by cultured spermatocysts (Sertoli/germ cell units) and isolated Sertoli cells from Squalus testis. In "Proceedings of the 10th Annual Testis Workshop, Baltimore," 25.

Enders GC, Millette CF (1988): Pachytene spermatocyte and round spermatid binding to Sertoli cells in vitro. J Cell Sci 90:105-114.

Foucher JL, Le Gac F (1989): Evidence for an androgen binding protein in the testis of a teleost fish (Salmo gairdneri R.): A potential marker of Sertoli cell function. J Steroid Biochem 32:545-552.

Fremont L, Marion D (1982): A comparison of the lipoprotein profiles in male trout (Salmo gairdneri) before maturity and during spermiation. Comp Biochem Physiol 73B:849-855.

Hadley MA, Byers SW, Suarez-Quian CA, Kleinman HK, Dym M (1985): Extracellular matrix regulates Sertoli cell differentiation, testicular cord formation, and germ cell development in vitro. $\mathrm{J}$ Cell Biol 101:1511-1522.

Iatrou K, Spira AW, Dixon GH (1978): Protamine messenger ARN: Evidence for early synthesis and accumulation during spermatogenesis in rainbow trout. Dev Biol 64:82-98.

Imbenotte J, Verger C, Sassa S (1985): Modulation of cell attachment to culture support by pH, fibronectin, hemin and cobalt protoporphyrin. J Cell Physiol 124:358-362.

Kiyotaka Y, Abe S (1983): Inhibition of second meiotic division and a switching over to flagellar formation in secondary spermatocytes of newt by cycloheximide. Exp Cell Res 144:265-274.

Le Gac F, Loir M (1988): Control of testis function in fish: in vitro studies of gonadotropic regulation in the trout (Salmo gairdneri). Reprod Nutr Dev 28:1031-1046.

Le Magueresse B, Jégou B (1988): In vitro effects of germ cells on the secretory activity of Sertoli cells recovered from rats of different ages. Endocrinology 22:1672-1680.

Loir M (1988): Trout Sertoli and Leydig cells: Isolation, separation, and culture. Gamete Res 20:437-458.

Loir M, Wyrobek A (1972): Density separation of mouse spermatid nuclei. Exp Cell Res 75:261-265.

Palombi F, Ziparo E, Rommerts FFG, Grootegoed JA, Antonini M, Stefanini M (1979): Morphological characteristics of male germ cells of rats in contact with Sertoli cells in vitro. J Reprod Fertil 57:325-330.

Phillips HJ (1973): Dye exclusion tests for cell viability. In Kruse RF, Patterson MK (eds): “Tissue Culture." New York: Academic Press, pp 406-408.

Remacle C (1976): Actions hormonales sur les cellules germinales males de Carassius auratus L. en culture organotypique. Gen Comp Endocrinol 29:480-491.

Risley MS (1983): Spermatogenic cell differentiation in vitro. Gamete Res 4:331-346. 
Romrell LJ, Bellve AR, Fawcett DW (1976): Separation of mouse spermatogenic cells by sedimentation velocity. Dev Biol 49:119-131.

Schulz R, Blüm V (1988): Testosterone immunoreactivity in rainbow trout (Salmo gairdneri Richardson) testis. Gen Comp Endocrinol 72:80-89.

Sprando RL, Russell LD (1987): A comparative study of Sertoli cell ectoplasmic specializations in selected non-mammalian vertebrates. Tissue Cell 19:479-493.

Tres LL, Kierszenbaum AL (1983): Viability of rat spermatogenic cells in vitro is facilited by their coculture with Sertoli cells in serum-free hormone supplemented medium. Proc Natl Acad Sci USA 80: 3377-3381.

Tung PS, Fritz IB (1984): Extracellular matrix promotes rat Sertoli cell histotypic expression in vitro. Biol Reprod 30:213-229.

Van den Hurk R, Peute J, Vermeij JAJ (1978): Morphological and enzyme cytochemical aspects of the testis and vas deferens of the rainbow trout, Salmo gairdneri. Cell Tissue Res 186:309-325. 